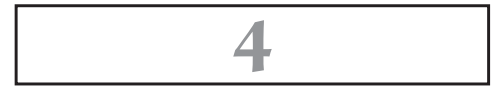

\title{
O GASTO PÚBLICO E O DOMÍNIO ECONÔMICO
}

\subsection{O GASTO PÚBLICO COMO MECANISMO DE INTERVENÇÃO NO DOMÍNIO ECONÔMICO}

Nos subitens a seguir, assim como fora feito ao estudar a receita tributária, tratar-se-á especificamente do gasto público e de sua utilização como instrumento de intervenção no domínio econômico.

Para tanto, serão apresentados os principais conceitos e a classificação das despesas públicas e, após breve análise acerca de seu caráter vinculativo, buscar-se-á demonstrar de que forma a previsibilidade do gasto público interfere na atividade desempenhada pela iniciativa privada e como esta reage, ou ao menos poderia reagir, diante das estimativas apresentadas pelo Estado.

Percorrido esse caminho, proceder-se-á ao estudo das subvenções econômicas e sua atual relevância para o domínio econômico; ao final, serão apresentados os principais problemas que podem surgir diante de uma política subvencionista.

\subsubsection{Conceito e classificação das despesas públicas}

Aliomar Baleeiro ${ }^{377}$ propõe dois conceitos de despesa pública: o primeiro "designa o conjunto de dispêndios do Estado, ou de outra pessoa de direito público, para o financiamento dos serviços públicos" e, o segundo, consiste na "aplicação de certa

7 BALEEIRO, Aliomar. Uma introdução à ciência das finanças, p. 65. 


\section{•• O orçamento como instrumento de intervenção no domínio econômico}

quantia, em dinheiro, por parte da autoridade ou agente público competente, dentro duma autorização legislativa, para execução de fim a cargo do governo".

Em outras palavras, e como sintetiza Ricardo Lobo Torres, pode-se dizer que "a despesa pública é a soma dos gastos realizados pelo Estado para a realização de obras e para a prestação de serviços públicos" ${ }^{378}$.

Após a entrada dos recursos, os quais provêm da arrecadação de tributos, do próprio patrimônio do Estado - exploração, arrendamento e venda de propriedades - e até mesmo da contratação de empréstimos públicos, como será observado adiante, o Estado toma a decisão de aplicá-los com o propósito de atender a determinadas finalidades, que, como visto, são previamente traçadas nas leis orçamentárias.

É por meio dessa decisão política, materializada no planejamento orçamentário, que o Estado obedece - ou ao menos deveria obedecer -, a determinados critérios para satisfazer as necessidades públicas e realizar investimentos.

Estabelecidas as prioridades, mediante prévia autorização legislativa (arts. 165 , $\$ \$ 5^{\circ}, 6^{\circ}$ e 9o, 167 e 169 da CF/1988), o Estado estará autorizado a realizar a despesa, ou seja, a promover a saída do dinheiro dos cofres públicos, o que também deve dar-se de acordo com as formas estabelecidas em lei ${ }^{379}$. Afinal, o Estado, por meio do gasto público, tem de adquirir material bélico; arcar com as despesas dos edifícios da Administração Pública em que funcionam os tribunais de justiça, as embaixadas etc.; pagar os salários de funcionários, dentre eles, policiais, juízes, diplomatas e empregados públicos; construir ou pagar a construção de pontes, estradas, ferrovias, hidrelétricas, hospitais, escolas; outorgar subsídios; conceder subvenções econômicas; realizar investimentos etc.

Para tanto, faz-se necessário distinguir as despesas públicas a fim de diferenciar devidamente as obrigações assumidas pelo Estado, as quais, de certa maneira, cada vez mais têm se mostrado heterogêneas entre si.

Embora vários critérios sejam satisfatórios, tomar-se-á como ponto de partida, o critério estabelecido na Lei n. 4.320/1964, que é preponderantemente econômico. Previsto no art. 12, o critério de que se vale a lei distingue as despesas públicas em: (i) despesas correntes, as quais estão fundamentalmente atreladas à realização de serviços e, que, por seu turno, dividem-se em (i.a) despesas de custeio e (i.b) transferências correntes; e em (ii) despesas de capital, as quais se vinculam à aquisição ou produção de bens e se classificam em: (ii.a) investimentos, (ii.b) inversóes financeiras e (ii.c) transferências de capital.

378 TORRES, Ricardo Lobo. Curso de direito financeiro e tributário, p. 194.

379 OLIVEIRA, Regis Fernandes de. Curso de direito financeiro, p. 292. 
O referido critério, como adverte Kleber Luiz Zanchim $^{380}$, não é aleatório e, como visto, leva em consideração as consequências produzidas pelas despesas públicas, individualmente. As primeiras, ditas correntes, não agregam ativos para o ente que as realiza, enquanto as últimas possuem exatamente essa finalidade, contribuindo para a introdução de um ativo no patrimônio do ente público.

Assim, classificam-se como despesas de custeio as dotações para manutenção de serviços anteriormente criados, inclusive as destinadas a atender a obras de conservação e adaptação de bens imóveis (art. 12, $\$ 1^{\circ}$ ), e dentre as quais se incluem as despesas com pessoal, material de consumo, serviço de terceiros etc. Já as transferências correntes compóem as dotações para despesas, às quais não corresponda contraprestação direta em bens ou serviços, inclusive para contribuições e subvenções destinadas a atender à manifestação de outras entidades de direito público ou privado (art. 12, $\$ 2^{\circ}$ ), incluindo as subvenções econômicas e sociais, as despesas com inativos, as pensões, as transferências intergovernamentais e os juros da dívida contratada ${ }^{381}$.

Dentre as despesas de capital, a qual está vinculada à aquisição ou produção de bens, encontram-se as despesas de investimentos, nelas compreendidas as dotaçôes para o planejamento e a execução de obras, inclusive as destinadas à aquisição de imóveis considerados necessários à realização destas últimas (art. 12, $\$ 4^{\circ}$ ); as inversões financeiras, compostas pelas dotações destinadas à aquisição de imóveis ou bens de capital já em utilização ou à aquisição de títulos representativos do capital de empresas ou entidades de qualquer espécie (art. 12, $\$ 5^{\circ}$ ); e, por fim, as transferências de capital, que são as dotações para investimentos ou inversões financeiras que outras pessoas de direito público ou privado devam realizar, independentemente de contraprestação direta em bens ou serviços. No caso dessas transferências, elas constituem auxílios ou contribuições, segundo derivem da Lei de Orçamento ou de lei especialmente anterior, bem como as dotaçóes para amortização da dívida pública.

Além da classificação econômica, os gastos públicos também podem ser classificados de acordo com sua periodicidade em: gastos ordinários ou extraordinários. Por intermédio dos gastos ordinários, como se deduz, busca-se atender às necessidades públicas estáveis, permanentes e periodicamente previstas no orçamento; os gastos extraordinários, por sua vez, têm como propósito satisfazer as necessidades

${ }^{380}$ ZANCHIM, Kleber Luiz. Capítulo III - da despesa: arts. 12 a 21. In: CONTI, José Maurício (Coord.). Orçamentos públicos: a Lei n. 4.320/1964 comentada, p. 71.

381 TORRES, Ricardo Lobo. Curso de direito financeiro e tributário, p. 195-196. 


\section{•• O orçamento como instrumento de intervenção no domínio econômico}

públicas momentâneas, de caráter esporádico, bem como acidentais, imprevisíveis, como despesas decorrentes de guerra, comoção interna ou intestina, calamidade pública, que, por serem urgentes e inadiáveis, não podem esperar o processo prévio da autorização legal.

Por fim, Ricardo Lobo Torres ${ }^{382}$ acrescenta, ainda, que subsistam outros critérios, por exemplo, que os gastos públicos também podem ser distinguidos de acordo com a instituição que os realiza, ou seja, por meio de um critério institucional, no qual se leva em conta o órgão ou a instituição a quem se atribui a realização do gasto (Ministério, Secretaria, Departamento etc.); ou mediante um critério programático, em que a despesa é classificada de acordo com o programa governamental a que se destina (ensino, saúde, transporte etc.).

Com efeito, verifica-se que o conceito de despesa pública está atrelado à necessidade pública e que qualquer que seja a forma de satisfação utilizada é indispensável que esta preexista para que o gasto se realize justificadamente. A realização de toda despesa ou a assunção de qualquer obrigação pelo Estado e seus agentes devem, assim, estar previamente estabelecidas nas leis orçamentárias, sob pena de serem consideradas não autorizadas, irregulares e lesivas ao patrimônio público.

\subsubsection{A despesa pública e seu caráter vinculativo}

A despeito de este estudo divergir da posição prevalecente, a qual defende ter o orçamento caráter meramente autorizativo, não há como afastar a teoria que busca dar maior efetividade à previsão orçamentária.

A tese defendida por Paul Laband, seguida por grande parte dos estudiosos, de que o orçamento é uma lei meramente formal, há muito deixou de ter o apoio da melhor doutrina, como sinaliza Ricardo Lobo Torres ${ }^{383}$ :

A teoria da lei formal se enfraqueceu nos últimos anos no Brasil, a exemplo do que acontecia nos Estados Unidos e em outros países, diante da emergência das normas constitucionais de vinculação da receita pública a despesas e fundos específicos (EC 14/1996, 17/1997, 27/2000, 29/2000, 30/2000, 37/2000, 42/2003 e 53/2006), da criação de tributos vinculados (contribuições previdenciárias, contribuições sociais exóticas para a seguridade social (PIS/COFINS, CSLL, CPMF) e contribuições de intervenção no domínio econômico) e as titulações criadas pelo Judiciário (precatórios, mandados de injunção e outras ações) para a garantia dos direitos fundamentais e do mínimo existencial. O enfraquecimento da teoria da lei formal caminhou para-

382 TORRES, Ricardo Lobo. Curso de direito financeiro e tributário, p. 196.

383 TORRES, Ricardo Lobo. Tratado de direito constitucional financeiro e tributário, p. 97. 
lelamente co a perda de substância do princípio da não-afetação e com a definição das despesas necessárias e dos efeitos da vinculação de recursos trazida pela Lei de Responsabilidade Fiscal (art. 8º, parágrafo único, e art. 17 da LC 101/2000), tudo o que ampliou o papel do Judiciário e minimizou a discricionariedade dos poderes políticos (Legislativo e Executivo).

$\mathrm{Na}$ Espanha, antes mesmo da promulgação da Constituição Federal brasileira de 1988, Álvaro Rodríguez Bereijo já mostrava ser adepto do pensamento de Sainz de Bujanda, ao afirmar que "a proibição de que pelo o orçamento se crie ou modifique o ordenamento jurídico vigente não constitui uma confirmação positiva da natureza formal da lei orçamentária" ${ }^{884}$.

No Brasil, Regis Fernandes de Oliveira ${ }^{385}$ foi taxativo ao afirmar que as despesas devem ser efetuadas de acordo com a previsão orçamentária por representar os anseios da sociedade:

A título de conclusão, pode-se afirmar que o orçamento é impositivo, não deixando margem a manobras, titubeios ou qualquer tergiversação do Governo, a pretexto de utilizá-lo como meramente autorizativo. Contém autorizações, com certeza, na arrecadação, mas as despesas devem ser efetuadas de acordo com o que foi determinado na lei orçamentária.

Caso contrário, como já se disse, teremos a desmoralização do Congresso que de nada serviria. Para que aprovar a lei orçamentária, se ela não será cumprida? Ao contrário, diante da Lei de Responsabilidade Fiscal, o orçamento deve ser executado tal como aprovado, pois, qualquer desvio envolve a responsabilidade do Chefe do Executivo.

Ao democratizar o processo legislativo do orçamento, restou conferido ao Poder Legislativo a prerrogativa de estabelecer as prioridades que vão condicionar a elaboração do projeto da lei orçamentária anual, o que se dá, como já assinalado, pela lei de diretrizes orçamentárias. Embora essa lei seja de iniciativa do Poder Executivo, o qual está adstrito a observar as indicaçôes contidas no plano plurianual, deve ser aprovada pelo Legislativo, que detém ampla liberdade de emendá-la, até mesmo modificando as prioridades indicadas pelo Executivo.

É o que se verifica também com a edição da Lei Complementar n. 101, de 4 de maio de 2000, conhecida como Lei de Responsabilidade Fiscal, a qual determina que os mandamentos da Lei n. 4.320/1964 sejam interpretados em consonância com os preceitos da Constituição Federal e impõe ao Administrador a obrigação de

384 BEREIJO, Álvaro Rodríguez. La configuración constitucional de las leyes de presupuestos generales del estado. Valadolid: Lex Nova, 1988. p. 31.

385 OLIVEIRA, Regis Fernandes de. Deve o orçamento ser cumprido? Jus Navegandi, Teresina, ano 9, n. 672, 8 maio 2005. Disponível em: <http://jus.com.br/revista/texto/6698/deve-o-orcamento-ser-cumprido>. Acesso em: 22 abr. 2013. 


\section{•• O orçamento como instrumento de intervenção no domínio econômico}

realizar uma gestão fiscal responsável, pressupondo uma atuação planejada e transparente, capaz de assegurar o equilíbrio das contas públicas, e que disciplina os diferentes orçamentos, a gestão financeira, o crédito público e a fiscalização de todas as atividades relacionadas ao gasto do dinheiro público ${ }^{386}$.

A necessidade de se conferir maior responsabilidade ao cumprimento do quanto estatuído no orçamento, afastando a pretensão de se afirmar que as dotações orçamentárias são desprovidas de qualquer caráter vinculativo, ganha força com a leitura do art. 21, inc. IX, da CF/1988, o qual atribui à União Federal a competência para "elaborar e executar planos nacionais e regionais de ordenação do território e de desenvolvimento econômico e social".

Não obstante, e conforme abordado anteriormente, o orçamento configura-se como verdadeiro plano de atuação do Estado, constituindo "a expressão da política geral do Estado" e, mais do que mero programa, "é um ato de direção política, pois determina a vontade estatal por meio de um conjunto de medidas coordenadas"387.

Para tanto, faz-se necessário dar maior efetividade ao planejamento das ações governamentais de longo prazo, minimizar a discricionariedade e a influência das paixôes, evitando desperdícios e impor um empreendimento do dinheiro público mais eficiente, de modo a melhor atender aos anseios da sociedade. Afinal, é por meio do orçamento que a Administração Pública cumpre suas funçôes, regula e intervém no campo social e econômico.

Em face da evolução e do tratamento dado à matéria pela Constituição Federal vigente, percebe-se nitidamente que as dotaçóes orçamentárias deixaram de ser meras autorizações, estando vinculadas à execução de determinados projetos ou programas, determinantes para a Administração e para a sociedade, o que é esclarecido com propriedade por José Maurício Conti ${ }^{388}$, ao sintetizar a evolução do orçamento:

Inicialmente, esses incipientes orçamentos públicos eram documentos que tinham o caráter de peças contábeis, em que se faziam as previsões de receitas e autorizações de despesas para um determinado período - o exercício financeiro. Essa é, em síntese, o que se denomina concepção clássica do orçamento.

${ }^{386}$ DALLARI, Adilson Abreu. Orçamento impositivo. In: CONTI, José Maurício; SCAFF, Fernando Facury. (Coord.). Orçamentos públicos e direito financeiro, p. 312.

387 BERCOVICI, Gilberto. Constituição econômica e desenvolvimento: uma leitura a partir da Constituição de 1988, p. 69.

388 CONTI, José Maurício. A autonomia financeira do poder judiciário. São Paulo: MP Editora, 2006. p. 57. 
As necessidades da Administração Pública, aliadas ao desenvolvimento das técnicas orçamentárias, foram aos poucos modificando a concepção clássica do orçamento público, fazendo com que assumisse uma função importante na condução das políticas públicas. Vários fatores influíram nessa tendência, destacando-se o intenso intervencionismo estatal nas atividades econômicas.

$\mathrm{O}$ autor ${ }^{389}$ prossegue em seu relato:

$\mathrm{O}$ orçamento torna-se um instrumento fundamental no planejamento e na programação da atividade econômica do Governo, adquirindo, como bem ressalta Giuliani Fonrouge, uma condição dinâmica, e tornando-se "un instrumento mediante el cual el Estado actúa sobre la economia".

As técnicas e os conceitos orçamentários modernos refletem essa nova função dos orçamentos públicos, surgindo os conceitos de orçamento-programa, orçamento de desempenho (performance budget) e PPBS (planing, programming and budgeting system), que, embora não tenha distinção nítida entre si, demonstram que o orçamento, inequivocamente, abandona sua concepção clássica para assumir a condição de instrumento de ação governamental.

Ainda que as considerações apresentadas bastem para reconhecer o caráter impositivo do orçamento, verifica-se que a controvérsia ganha mais força se colocada na disputa entre o Executivo e o Legislativo, no que concerne à liberação de verbas das emendas de deputados e senadores pelo Executivo, o qual, diante do caráter meramente autorizativo da lei orçamentária, motivou a apresentação de várias proposições legislativas que tendem a introduzir a figura do denominado orçamento impositivo no ordenamento brasileiro, como aponta Luís Otávio Barroso da Graça ${ }^{390}$ :

Uma questão que tem hoje recebido severas críticas está relacionada à liberação de verbas das emendas de deputados e senadores pelo Poder Executivo. Como este não tem obrigação de executar determinadas ações, têm os parlamentares que solicitar o atendimento dos projetos para os quais destinaram recursos por meio de emendas. Alguns entendem que tais solicitações, conhecidas por "barganhas", retiram autonomia do Poder Legislativo e o colocam em situação de inferioridade frente ao Executivo. A adoção do orçamento impositivo (no todo ou em parte), portanto, tenderia a resolver essa situação, na medida em que não restaria ao Poder Executivo outra solução que não a de executar as emendas parlamentares.

389 Ibidem, p. 58.

390 GRAÇA, Luís Otávio Barroso da. Orçamento impositivo: uma análise à luz da economia política. 2003. 79 f. Dissertação (Mestrado em Economia do Setor Público) - Universidade de Brasília-UnB, 2003, f. 11/12. Disponível em: <http://www2.senado.gov.br/bdsf/item/id/88438>. Acesso em: 22 abr. 2013. 
Uma das primeiras propostas legislativas que abordou o caráter impositivo do orçamento, ainda que indiretamente, foi o Projeto de Lei Complementar de n. 135/1996. Destinado a promover a alteração da Lei n. 4.320/1964, detinha como fim precípuo regulamentar o art. $165, \$ 9^{\circ}, \mathrm{da} \mathrm{CF} / 1988$, e atribuir certo caráter de obrigatoriedade à execução orçamentária, impondo ao Poder Executivo, caso pretendesse deixar de executar o quanto previsto na lei orçamentária, a obrigatoriedade de encaminhar ao Congresso Nacional um projeto de lei de anulação, a fim de desvincular a receita e a obrigatoriedade do gasto.

Tramitam no Congresso brasileiro, também, várias outras propostas de emendas constitucionais, cujo intuito é impor a aplicação de determinados percentuais das receitas em ações e serviços; restringir o contingenciamento de emendas individuais dos parlamentares pelo Poder Executivo; estabelecer limite para abertura de créditos extraordinários e, além disso, promover a implementação de um suposto orçamento impositivo ${ }^{391}$.

Ainda que restrito a uma parcela inferior a $10 \%$ do orçamento, pois todo o resto já detém destinação certa, ou melhor, já se encontra vinculado a determinada atividade, investimento ou realização de despesa como gastos com pessoal e pagamento da dívida pública (art. $9^{\circ}, \$ 2^{\circ}$, da LC 101/2000), muito se discute acerca da implementação ou não do denominado orçamento impositivo, o que recairá sobre as despesas ditas discricionárias.

Além das Propostas de Emendas Constitucionais anteriormente citadas, restou aprovada em 12 de novembro de 2013 pelo Senado Federal e em primeiro turno pela Câmara dos Deputados, em 6 de maio de 2014, a PEC 22A/2000, então conhecida como "Proposta de Emenda à Constituição do Orçamento Impositivo". Apresentada originariamente pelo então senador Antonio Carlos Magalhães, no ano de 2000, os senadores e líderes governistas preveem que ela possibilitará à área da saúde orçamento de pelo menos $\mathrm{R} \$ 64$ bilhões a mais até 2018. Essa PEC estabelece, ainda, a obrigatoriedade de executar as emendas parlamentares até o limite de $1,2 \%$ da receita corrente líquida (RCL) do exercício anterior; desse total, $50 \%$, ou seja, $0,6 \%$ da RCL deverão ser aplicados na área de saúde.

391 PEC 236/2012; PEC 201/2012; PEC 182/2012; PEC 156/2012; PEC 152/2012; PEC 20/2011; PEC 417/2009; PEC 321/2009; PEC 281/2008; PEC 127/2007; PEC/102/2007; PEC 96/2007; PEC 46/2007; PEC 565/2006; PEC 480/2005; PEC 385/2005; PEC 229/2204 etc. Disponível em: <http://www2.camara.leg.br/>. Acesso em: 14 maio 2013. 
Antes da aprovação da PEC 22A/2000, José Maurício Conti, ao comentar as declarações prestadas pelo então Presidente da Câmara dos Deputados, Henrique Eduardo Alves, que manifestava sua intenção em acelerar a tramitação da Proposta de Emenda Constitucional n. 565/2006 392 , já externou sua posição, corroborando com a tese defendida por Regis Fernandes de Oliveira ${ }^{393}$, nos seguintes termos:

Mas, independentemente das razões que a justificam, e até do fato de os interesses que a sustentam terem dimensões menores do que a questão jurídica de fundo, o fato é que a aprovação desta emenda constitucional promoverá um importante avanço no sentido de se fazer respeitar a lei orçamentária. Colaborará decisivamente para lhe conferir maior eficácia e credibilidade - o que já é uma evolução para o que se espera de um futuro próximo, que é a máxima "impositividade" do orçamento -, e contribuirá para o respeito à democracia, à vontade popular expressa por ocasiáo da aprovação da lei orçamentária, à independência e autonomia dos poderes e ao planejamento e gestão eficiente da administração pública, elementos essenciais para o desenvolvimento econômico e social.

Aqueles que se contrapõem ao orçamento impositivo, por sua vez, argumentam que este não é "uma fórmula garantidora das previsões que o contém, isto é, o orçamento não pode garantir que as previsões orçamentárias sejam realizadas concretamente. Estas dependem do desempenho econômico e de decisões políticas que a confirmem"394.

Mesmo que se alegue que o orçamento não pode garantir que as previsões orçamentárias sejam realizadas concretamente ou que estaria reduzida a discricionariedade, o Executivo deterá instrumentos capazes de afastar eventual dotação que se mostre impossível de se realizar, bastando, para tanto, justificar sua pretensão ao Legislativo que, diante do caso em concreto, não terá como se opor.

Nota-se, assim, que o orçamento detém um caráter vinculante no que toca às dotações orçamentárias, devendo-se deixar de lado os costumes arraigados, sedimentados há longo tempo, a fim de que as despesas sejam realizadas como previsto na lei orçamentária.

392 ALVES, Henrique Eduardo. Orçamento respeitosamente impositivo. Folha de S. Paulo. São Paulo, 14 abr. 2013. Seção Tendências/Debates, p. A3.

393 CONTI, José Maurício. Orçamento impositivo é avanço para administração. Consultor Jurídico, 7 maio 2013. Disponível em: <http://conjur.com.br/2013-maio-07/contas-vista-orcamento-impositivo-avanco-adminstracao >. Acesso em: 6 out. 2014.

394 SEGUNDO, Rinaldo. Breves considerações sobre o orçamento público. Jus Navegandi, 2002. Disponível em: <http://jus.com.br/revista/texto/4505/breves-consideracoes-sobre-o-orcamento-publico>. Acesso em: 30 jun. 2013. 


\subsubsection{A previsibilidade do gasto público como fator de indução e regulação da atividade econômica}

Já se disse, linhas atrás, que o Poder Público elege, politicamente, como atenderá às necessidades públicas e, assim, como realizará o gasto público. Além disso, também se esclareceu que toda despesa deve estar previamente estabelecida em lei, sob pena de ser considerada não autorizada, irregular e lesiva ao patrimônio público, bem como se defendeu ser necessário conferir maior responsabilidade ao cumprimento do quanto estatuído no orçamento e afastar a pretensão de se afirmar que as dotaçôes orçamentárias são desprovidas de qualquer caráter vinculativo.

Com apoio nessas premissas, especialmente no tocante à previsibilidade da despesa pública, pode-se dizer que em uma economia em que constantemente são lançados como objetivos o pleno emprego, a estabilidade dos preços, a expansão da produção e a melhor distribuição de renda, essa previsibilidade exerce forte influência e deveria ser tratada com mais responsabilidade.

A propósito, como Héctor Belisario Villegas ${ }^{395}$ salienta:

Mediante el gasto público el Estado se moviliza para atender las necesidades de la población por medio de los servicios públicos, cuyo destino es la cobertura de las necesidades públicas. Pero también el Estado puede satisfacer dichas necesidades con prescindencia de los servicios públicos y utilizando los efectos que "en sí mismos" los gastos públicos provocan en la economía nacional, atento a su importancia cuantitativa y cualitativa (p. ej.: un incremento considerable en la cuantía del gasto público puede obrar como reactivador de una economía en recesión con prescindencia del destino del gasto).

Não por menos, valendo-se da teoria proposta por John Maynard Keynes, e de forma pontual, Alejandro Ramirez Cardona ${ }^{396}$ assinala que o gasto público, assim como o gasto realizado pelo setor privado, é capaz de produzir efeitos multiplicadores. Por meio do gasto público verifica-se incremento na renda nacional e, consequentemente, aumento do consumo e do investimento na economia.

Nesse sentido, recorda Benvenuto Griziotti ${ }^{397}$ que o Estado passou dos gastos extremamente vinculados à tutela jurídica e à defesa militar, para os gastos gerais favoráveis ao desenvolvimento demográfico e à prosperidade da nação.

Para Fábio Nusdeo ${ }^{398}$, o governo, nesse caso, gasta de duas formas: "a) absorvendo mão de obra ainda não empregada pelas empresas; e b) investindo parte dos

\footnotetext{
395 VILLEGAS, Héctor Belisario. Curso de finanzas, derecho financiero y tributario, 9. ed., p. 32.

396 CARDONA, Alejandro Ramirez. Sistema de hacienda pública, p. 160.

397 GRIZIOTTI, Benvenuto. Principios de ciencia de las finanzas, p. 66.

398 NUSDEO, Fábio. Curso de economia: introdução ao direito econômico, p. 291.
} 
recursos em obras ou serviços públicos, os quais, por seu turno, incrementariam o nível de atividade das empresas, levando-as a contratar mais membros das famílias".

O Estado atua, mediante a realização da despesa pública, como indutor da economia, nela intervindo e estimulando as empresas a melhorarem ou expandirem sua capacidade produtiva, o que se dará com a realização de investimentos em máquinas, instalações, equipamentos, ampliação de estoques, contratação de novos funcionários etc. ${ }^{399}$

Com base no exposto, torna-se possível deduzir a razão pela qual a Lei n. 4.320/1964 estabelece um critério de divisão preponderantemente econômico, em que as despesas correntes refletem "a ideia de 'aparelhamento do Estado', ou crescimento da máquina pública, enquanto as despesas de capital são vistas como fator de promoção do desenvolvimento econômico" ${ }^{\text {«00 }}$.

Enquanto as despesas correntes são vistas com preocupação por refletirem os gastos do Estado e exercerem influência direta na apuração do superávit primário ${ }^{401}$; as despesas de capital adquirem cunho "desenvolvimentista", pois fomentam o crescimento econômico e melhoram a capacidade do país de honrar suas dívidas ${ }^{402}$.

Ao prever o quanto e de que forma gastará os recursos públicos, valendo-se do planejamento como instrumento ou ferramenta para alcançar seu fím único - o interesse público -, o Estado traça seus objetivos e metas prioritárias, e define os modos operacionais com que pretende alcançá-los. Em suma, o Estado apresenta à sociedade e, portanto, ao domínio econômico, seu plano de atuação, influenciando o domínio econômico a tomar decisões positivas ou negativas.

Como bem recorda Kleber Luiz Zanchim ${ }^{403}$, o PPI foi utilizado pela primeira vez em 2009, para ajustar as metas de superávit primário e, com a redução da arrecadação tributária, em face da crise financeira internacional, o governo optou por realizar investimentos com o propósito anticíclico.

399 NUSDEO, Fábio. Curso de economia: introdução ao direito econômico, p. 293.

400 ZANCHIM, Kleber Luiz. Capítulo III - da despesa: arts. 12 a 21. In: CONTI, José Maurício Coord.). Orçamentos públicos: a Lei n. 4.320/1964 comentada, p. 72.

401 O superávit primário, a grosso modo, é composto pelo saldo positivo entre receitas e despesas, excluídas as receitas de juros e capital e as despesas com juros, amortizações e correções da dívida pública.

${ }^{402}$ ZANCHIM, Kleber Luiz ZANCHIM, Kleber Luiz. Capítulo III - da despesa: arts. 12 a 21. In: CONTI, José Maurício Coord.). Orçamentos públicos: a Lei n. 4.320/1964 comentada, p. 73.

${ }^{403}$ ZANCHIM, Kleber Luiz ZANCHIM, Kleber Luiz. Capítulo III - da despesa: arts. 12 a 21. In: CONTI, José Maurício Coord.). Orçamentos públicos: a Lei n. 4.320/1964 comentada, p. 73. 
Nesse aspecto, são pertinentes as considerações de Richard A. Musgrave ${ }^{404}$ que, ao abordar os aspectos relativos às compras públicas e, portanto, decorrentes da execução do orçamento, cita a possibilidade de o governo conceder contratos a pequenos fornecedores, ou, então, aos que se localizem em certas áreas, ainda que seus preços sejam maiores, refletindo, a política de compra, uma combinação de objetivos que envolvem considerações distributivas sociais ou de defesa.

Com isso, verifica-se que o Estado intervém, ainda que indiretamente, na economia, induzindo-a a agir ou deixar de agir de acordo com o que for mais importante para a sociedade em dado momento. Essa interferência, como assinala Regis Fernandes de Oliveira ${ }^{405}$, deve dar-se de forma objetiva, pois:

Em termos de economia interna, o que vale é assentar sua decisão no interior de um conhecimento exaustivo da realidade brasileira e induzir a economia naquilo que for mais importante naquele dado momento histórico.

As despesas atenderão, assim, a realidades econômicas objetivas. Sem dúvida que a tomada de decisão é subjetiva, mas cercada pelo máximo de objetividade possível, ou seja, informações sobre o mercado, como ele está funcionando, quais as paralelas imprescindíveis para o encaminhamento econômico do país.

Tem-se, com isso, que a previsão das despesas públicas influi diretamente sobre os rumos da economia de um país, consistindo importante instrumento de redistribuição de renda, de estabilização econômica e de incremento da renda nacional; ela exerce forte influência sobre os aspectos mais essenciais, como o emprego e a renda, o consumo e o desenvolvimento ${ }^{406}$.

Logo, atrelada ao planejamento orçamentário, o gasto público tendente à realização das políticas públicas e, com isso, a satisfação dos interesses públicos, deve ser adequadamente estruturado e se dar em consonância com os objetivos e a capacidade da iniciativa privada em determinado momento histórico, sob pena de impedir ou reduzir o crescimento econômico almejado.

Novamente mostra-se de salutar relevância a adoção de um planejamento responsável e seu fiel cumprimento, de modo a assegurar a adoção de medidas corretivas decorrentes das reações do mercado às intenções do próprio Estado ou provocadas por fatores externos e imprevisíveis, como, por exemplo, guerras, crises econômicas, medidas de proteção ou restritivas de mercado impostas por outros países.

${ }^{404}$ MUSGRAVE, Richard A. Teoria das finanças públicas. São Paulo: Atlas, 1974. v. 2, p. 75.

405 OLIVEIRA, Regis Fernandes de. Gastos públicos, p. 18.

${ }^{406}$ VILLEGAS, Héctor Belisario. Curso de finanzas, derecho financiero y tributario, 9. ed., p. 34. 


\subsection{AS SUBVENÇÕES ECONÔMICAS}

Apresentado esse breve exame dos contornos envolvendo as despesas públicas, seu caráter vinculativo e as principais implicações para o domínio econômico, faz-se pertinente proceder à análise das subvenções econômicas, pois implicam custos e, consequentemente, gasto para o Erário.

Essas subvenções, afinal, constituem um gasto público destinado a auxiliar em termos financeiros entidades públicas e privadas, devendo obrigatoriamente estar prevista no orçamento. Além disso, pretende-se demonstrar como sua utilização tem se dado e os principais problemas decorrentes do emprego deste importante instrumento sem critérios e planejamento.

\subsubsection{Conceito, distinções e características}

O instituto da subvenção sempre encontrou, no campo jurídico, considerável diversidade de conceitos e aplicações. Diante da ausência de conteúdo específico, muitos ainda se valem do termo como sinônimo de subsídio ou de renúncia de receita, empregando-os como palavras identificadoras de auxílio, ajuda e até mesmo socorro financeiro, sem precisão terminológica alguma.

Para os propósitos do presente estudo, os subsídios, ao contrário das subvençôes, de um lado, consistem em um auxílio de caráter não orçamentário e, de outro, conforme Gaston Jèze ${ }^{407}$, pode ser entendido por subvenção

(...) una suma de dinero que se entrega periódicamente o en su totalidad y que tiene por objeto facilitar el funcionamiento de la obra o establecimiento privado que persigue una finalidad de interés general. Esta subvención no transforma dicha obra o estabelecimiento en servicio público, ya que sigue siendo privado.

Com efeito, constitui a subvenção um verdadeiro auxílio financeiro que deve estar previsto no orçamento público e que se destina a ajudar entidades públicas ou particulares a desenvolver atividades assistenciais, culturais ou empresariais ${ }^{408}$.

A propósito, o sistema financeiro nacional, de acordo com o $₫ 3^{\circ}$, do art. 12 da Lei n. 4.320/1964, distingue as subvençōes em duas espécies: (i) as sociais, especificamente destinadas a instituições públicas e/ou privadas de caráter assistencial ou cultural, sem fins lucrativos; e (ii) as econômicas, destinadas a "empresas públicas" ou privadas de caráter industrial, comercial, agrícola ou pastoril.

${ }^{407}$ JÈZE, Gaston. Principios generales del derecho administrativo, p. 53.

408 OLIVEIRA, Regis Fernandes de. Curso de direito financeiro, p. 445. 
Verifica-se, assim, que as subvenções econômicas adquirem e constituem verdadeiro instrumento de política financeira, definido de acordo com as transferências ou prestações monetárias prestadas em favor de entidades privadas pelo setor público, que, ao invés de esperar destas uma contraprestação na economia de mercado, ou seja, que os agentes econômicos ajam de forma livre, com pouca ou nenhuma intervenção estatal, tem por expectativa, geralmente, o fomento de determinado tipo de comportamento.

Compreende-se, assim, que as subvenções econômicas, em específico, constituem um auxílio financeiro destinado a ajudar, auxiliar e socorrer entes públicos e privados no desenvolvimento de suas atividades e têm como fator determinante a realização ou incentivo à prática de determinado ato.

O art. 19 da Lei n. 4.320/1964 proíbe o Estado de prestar ajuda financeira a empresas cujas atividades tenham fins lucrativos, mas também o autoriza a prestar ajuda financeira a empresas sem fins lucrativos quando se tratar de subvenções cuja concessão tenha sido expressamente autorizada em lei especial. Em suma, a subvenção econômica pode ser concedida em favor de empresas públicas e privadas, com ou sem fins lucrativos, sendo certo que nesta última hipótese deve ser implementada por lei específica.

As subvençōes econômicas caracterizam-se, assim, por consistirem um auxílio financeiro prestado pelo Estado; destinarem-se a fomentar a atividade de entidades públicas e privadas, de caráter industrial, comercial, agrícola ou pastoril, com ou sem fins lucrativos.

Ocorre que, embora sejam aceitas naturalmente como algo que constitui uma realidade da atividade econômica, muitos deixam de levar em consideração as diversas formas e modos de manifestação das subvenções econômicas, o que contribui para a ausência de controle e mensuração dos resultados pretendidos, suas implicações orçamentárias, que vão desde o aumento de tributos à qualidade do gasto público, e, ainda, sua incidência em face do funcionamento do processo econômico.

\subsubsection{Relevância e importância das subvenções econômicas}

As subvençôes econômicas constituem verdadeiro instrumento de intervenção e fomento à economia, destinados, conforme salientado, a servir de auxílio financeiro a empresas públicas e privadas de caráter industrial, comercial, agrícola ou pastoril ${ }^{409}$

${ }^{409}$ Art. $12, \$ 3^{\circ}$, inc. II, da Lei n. 4.320/1964. 
e têm como propósito, de acordo com o art. 18 da Lei n. 4.320/1964: (i) a cobertura dos déficits de manutenção das empresas públicas; (ii) a cobertura das diferenças entre os preços de mercado e os preços de revenda, pelo Governo, de gêneros alimentícios ou outros materiais; e (iii) o pagamento de bonificações a produtores de determinados gêneros ou materiais.

Caracteriza-se como incentivo financeiro, já que auxilia no financiamento, orienta e induz o produtor a determinada atividade. É preciso esclarecer, que os beneficiários das subvenções econômicas são apenas empresas e, portanto, pessoas jurídicas de direito privado, dentre as quais não se incluem as autarquias ${ }^{410} \mathrm{e}$ fundações públicas ${ }^{411}$, por serem consideradas entes não empresariais de direito público.

Além das considerações apresentadas, é preciso ressaltar que o caput do art. 18 da Lei em comento, ao fazer menção às "empresas públicas, de natureza autárquica”, deve ser interpretado em consonância com o Decreto-Lei n. 200, de 25 de fevereiro de 1967, o qual distinguiu a figura das autarquias, empresas públicas, sociedades de economia mista e fundações públicas, inexistindo, no regime brasileiro atual, a figura da "empresa pública de natureza autárquica", mencionada em referido dispositivo legal.

Com isso, e de acordo com o caput do art. 18 da Lei n. 4.320/1964, somente as empresas privadas, públicas e sociedades de economia mista podem receber transferências correntes para enfrentar seus déficits de manutenção, ou seja, despesas

410 As autarquias são definidas como sendo "pessoas jurídicas de Direito Público de capacidade exclusivamente administrativa” (MELLO, Celso Antônio Bandeira de. Curso de direito administrativo, p. 160).

411 De acordo com o Decreto-Lei n. 200, com a alteração introduzida pela Lei n. 7.596, de 10 de abril de 1987, compreende-se por fundação pública "a entidades dotada de personalidade jurídica de Direito Privado, sem fins lucrativos, criada em virtude de autorização legislativa, para o desenvolvimento de atividades que não exijam execução por órgãos ou entidades de Direito Público, com autonomia administrativa, patrimônio gerido pelos respectivos órgãos de direção, e funcionamento custeado por recursos da União e de outras fontes". Para Celso Antônio Bandeira de Mello, "É absolutamente incorreta a afirmação normativa de que as fundações públicas são pessoas de Direito Privado. Na verdade, são pessoas de Direito Público (...). O que se passou, entretanto, no Direito brasileiro é que foram criadas inúmeras pessoas designadas como 'fundaçôes', com atribuições nitidamente públicas, e que, sob o este aspecto, em nada se distinguem das autarquias. $\mathrm{O}$ regime delas estaria inevitavelmente atrelando-as às limitações e controles próprios das pessoas de Direito Público. Entretanto, foram batizadas de pessoas de Direito Privado apenas para se evadirem destes controles moralizadores ou, então, para permitir que seus agentes acumulassem cargos e empregos, o que lhes seria vedado se fossem reconhecidas como pessoas de Direito Público" (ibidem, p. 184). 


\section{•• O orçamento como instrumento de intervenção no domínio econômico}

de custeio e não de capital, as quais se subdividem em despesas de investimentos, de inversões financeiras e transferências de capital, nos termos do art. 12 da mencionada Leii ${ }^{412}$.

Feitas essas considerações, tem-se que na primeira hipótese, a qual consiste na concessão de subvenção para a "cobertura dos déficits de manutenção das empresas públicas", ou seja, aquelas que se originam da diferença negativa entre receitas e despesas correntes, é excepcional ${ }^{413}$ e limitada a empresas controladas pelo Poder Público.

Nas demais hipóteses, consagradas nas alíneas $a$ e $b$ do parágrafo único do art. 18, é que são destinadas a empresas privadas, as quais, como já salientado, podem receber ajuda financeira ainda que detenham fins lucrativos, mas tão somente se contar com autorização de lei especial, nos termos do art. 19.

Logo, a subvenção econômica, se não concedida a empresa sem fins lucrativos, só é possível mediante expressa previsão legal, sem a qual inexistirá a possibilidade do ato liberatório, não se tratando, portanto, de mera liberalidade, pois condicionado está ao cumprimento de diversos requisitos, dentre os quais aqueles expressos no Decreto n. 93.872/1986: (i) concessão prevista em lei especial (art. 61); (ii) prévia comprovação de regularidade fiscal do beneficiário (art. 62); (iii) comprovação do bom e regular emprego dos recursos percebidos; (iv) comprovação dos resultados alcançados (art. 66); e (v) que seu emprego atenda ao ônus ou encargo assumido pela União (art. 12, $\$ 6^{\circ}$ da Lei n. 4.320/1964).

Em termos constitucionais, verifica-se a existência de uma única vedação no que toca à possibilidade jurídica de subvencionar, adstrita aos cultos religiosos ou igrejas (art. 19, I, da CF/1988). Nesse caso, levou-se em consideração o fato de o Brasil ser uma República Federativa leiga ou laica, uma vez que há separação total entre Estado e Igreja e, inexistindo religião oficial, destaca-se a vedação constitucional de instituiçãoo de impostos pela União, Estados, Distrito Federal e Municípios sobre templos de qualquer culto (art. 150, VI, $b$, da CF/1988).

Em face do exposto, conclui-se que qualquer empresa pública ou privada pode perceber auxílio financeiro do Estado, desde que atendidos e preenchidos os requisitos impostos por lei, independentemente de contraprestação direta em bens ou serviços.

412 O Tribunal de Contas da União (TCU) já se manifestou nesse sentido ao impugnar a aplicação de subvenção em despesas de capital: TCs-575.664/1995-2, Acórdão n. 556/2000-1ª Câmara; 575.518/1995-2, Acórdão n. 628/2000-2a Câmara; 575.616/1995-4, Acórdão n. 629/2000-2a Câmara; 575.431/1995-4, Acórdão n. 269/2002-2a Câmara; e 575.611/1995-2, Acórdão n. 475/2002-1ª Câmara.

413 OLIVEIRA, Regis Fernandes de. Curso de direito financeiro, p. 446. 


\subsubsection{Os problemas decorrentes de uma política subvencionista e a necessidade de se empreender maior controle e fiscalização}

Como anota Gaston Jèze, politicamente, a concessão de subvenção pode ser muito vantajosa para a Administração:

“infaliblemente, la subvención cuesta menos que la trasformación en servicio público propriamente dicho. En primer lugar, una parte de los gastos seguirá a cargo de la obra o establecimiento; la Administración asumirá sólo una parte de ellos”¹4.

Nesse aspecto, Ricardo Lobo Torres anota com precisão que, por meio da política de privatizaçōes, o Estado conseguiu transferir para a iniciativa privada amplos setores das empresas estatais, o que consistiu na primeira grande reforma tendente a permitir o florescimento do Estado Fiscal ${ }^{415}$.

Com efeito, ao se levar em consideração alguns dados econômicos, os quais foram condicionantes para o alcance de certa estabilidade macroeconômica e institucional, a criação e a instituição de qualquer política de inclusão social e até mesmo a melhoria da distribuição de renda, será possível notar que as subvenções econômicas adquiriram significativa importância e, em muitos casos, tornaram-se indispensáveis para determinados setores da economia.

Ainda que a Lei n. 8.429, de 2 de junho de 1992 - conhecida como Lei de Improbidade Administrativa -, imponha sanções aos beneficiários ${ }^{416}$, não restam dúvidas que o Estado tem se valido das subvençôes econômicas para atingir os objetivos apontados há pouco, utilizando-as como método de intervenção no domínio econômico.

É o que se extrai da Lei n. 12.096/2009, por meio da qual a União Federal autoriza a concessão de subvenção econômica no valor correspondente a R \$ 402

414 JÈZE, Gaston. Principios generales del derecho administrativo, p. 53

415 TORRES, Ricardo Lobo. Tratado de direito constitucional, financeiro e tributário: o orçamento na Constituição, p. 44.

416 Conforme disposto a seguir: "Art. $1^{\circ}$. Os atos de improbidade praticados por qualquer agente público, servidor ou não, contra a administração direta, indireta ou fundacional de qualquer dos Poderes da União, dos Estados, do Distrito Federal, dos Municípios, de Território, de empresa incorporada ao patrimônio público ou de entidade para cuja criação ou custeio o erário haja concorrido ou concorra com mais de cinquenta por cento do patrimônio ou da receita anual, serão punidos na forma desta lei.

Parágrafo único. Estão também sujeitos às penalidades desta lei os atos de improbidade praticados contra o patrimônio de entidade que receba subvenção, benefício ou incentivo, fiscal ou creditício, de órgão público bem como daquelas para cuja criação ou custeio o erário haja concorrido ou concorra com menos de cinquenta por cento do patrimônio ou da receita anual, limitando-se, nestes casos, a sanção patrimonial à repercussão do ilícito sobre a contribuição dos cofres públicos." (Sem grifo no original.) 


\section{•• O orçamento como instrumento de intervenção no domínio econômico}

bilhões ao Banco Nacional de Desenvolvimento Econômico e Social (BNDES), para operações de financiamento destinadas à aquisição e produção de bens de capital e à inovação tecnológica ${ }^{417}$; do Decreto n. 8.079, de 20 de agosto de 2013, alterado pelo Decreto n. 8.183, de 17 de janeiro de 2014 e que regulamenta a Medida Provisória n. 615, de 17 de maio de 2013, concedendo até R $\$ 148$ milhões para o pagamento de subvenção econômica extraordinária aos produtores fornecedores independentes de cana de açúcar e às unidades industriais produtoras de etanol combustível que desenvolvam suas atividades na Região Nordeste, referente à produção da safra 2011/2012 e em tantas outras.

Em específico no setor agropecuário, nota-se maior incidência de concessão de subvençōes $^{418}$. A análise dos custos fiscais envolvendo as subvenções econômicas concedidas ao referido setor também possibilita verificar que as políticas de auxílio financeiro estão basicamente divididas em dois grupos, de acordo com a própria Organização para a Cooperação e Desenvolvimento Econômico (OCDE). O primeiro grupo, inerente aos atos de comercialização, é considerado política de suporte

417 Trata-se de subsídio governamental dado aos produtores brasileiros. Por meio da equalização, o governo cobre a diferença entre a taxa de juros praticada no mercado financeiro e a taxa efetivamente paga pelo produtor. Para ilustrar, cite o seguinte exemplo: o governo define que o empréstimo para custeio da safra terá juros de $5 \%$ ao ano. Se para a mesma operação o mercado financeiro cobrar uma taxa de $20 \%$, a diferença (15 pontos percentuais) será paga pelo Tesouro Nacional, que emitirá títulos públicos em favor dos bancos financiadores. Desse modo, os juros da agricultura ficam menores do que os praticados no mercado.

A equalização também pode ser feita em outros tipos de operação financeira e setores econômicos. Nas exportações, por exemplo, a política de equalização é usada para que as empresas brasileiras paguem as mesmas taxas cobradas no mercado internacional, permitindo que o produto nacional concorra em condições iguais às dos congêneres estrangeiros (Disponível em: <http://www2.camara.leg.br/camaranoticias/noticias/76087.html>. Acesso: 2 jul. 2014).

418 Lei n. 12.999/2014: autoriza o pagamento de subvenção econômica aos produtores da safra 2012/2013 de cana de açúcar da Região Nordeste; Lei n. 12.865/2013: autoriza, dentre outras medidas, o pagamento de subvenção econômica aos produtores da safra 2011/2012 de cana de açúcar e de etanol que especifica e o financiamento da renovação e implantação de canaviais com equalização da taxa de juros; Lei n. 12.877/2013: abre crédito extraordinário, em favor de encargos financeiros da União, no valor de $\mathrm{R} \$ 380$ milhões, para viabilizar o pagamento de subvenção econômica às unidades industriais produtoras de etanol combustível da Região Nordeste; Decreto n. 7.077/2010: regulamenta a Lei n. 9.445, de 14 de março de 1997, que concede subvenção econômica ao preço do óleo diesel consumido por embarcações pesqueiras nacionais; Decreto n. 6.252/2007: dispõe sobre a concessão de subvenção econômica nas operações de empréstimo e financiamento destinadas às empresas dos setores de pedras ornamentais, beneficiamento de madeira, beneficiamento de couro, calçados e artefatos de couro, têxtil, de confecção, inclusive linha lar, e de móveis de madeira etc. (Disponível em: <www. legislacao.planalto.gov.br>. Acesso: 2 out. 2014). 
baseada na produção de commodities; o segundo, adstrito ao crédito rural, em que a política de suporte se baseia no uso de insumos, tem como principal instrumento a equalização das taxas de juros, no âmbito tanto do Programa Nacional de Agricultura Familiar (Pronaf) quanto da agricultura industrial ${ }^{419}$.

Esses programas atingiram significativa relevância não apenas por sua essencialidade, mas, também, por conta do impacto que geram nos fatores macroeconômicos, como inflação e taxas de juros, não restando dúvidas que a provisão e os preços dos alimentos, quando fora de controle, podem gerar conflitos socioeconômicos, crises e impactos devastadores na economia.

O jornalista inglês Peter Popham ${ }^{420}$ corrobora a situação apontada, ao atribuir aos episódios de volatilidade dos preços das commodities à causa de tantas revoluçôes, citando como exemplo as crises no Oriente Médio e África.

Infere-se, assim, que a redução ou supressão de qualquer política subvencionista, ainda que a princípio seja precária e revogável e, portanto, possa ser alterada de acordo com sua eficácia e os propósitos da Administração Pública ${ }^{421}$, pode trazer efeitos indesejáveis, uma vez que determinados setores da atividade econômica se valem desses recursos financeiros para estruturar seus processos produtivos e de distribuição que, ao longo do tempo, tornam-se insubstituíveis ${ }^{422}$.

A delimitação das subvenções ao longo do tempo e a mensuração de sua eficácia, a qual está atrelada aos propósitos que ensejaram sua concessão, constituem um dos principais desafios para a Administração Pública, incumbida de fiscalizar as entidades beneficiadas e a utilização dos recursos públicos. Afinal, "a concessão de subvenção implica empobrecimento do Estado e enriquecimento da entidade que a recebe" ${ }^{\text {"423. }}$.

Ainda que a concessão da subvenção econômica pressuponha alguma contrapartida pelo beneficiário na forma como estabelecida nos instrumentos de ajuste

${ }^{419}$ Vejam-se programas instituídos pelo Ministério do Desenvolvimento Agrário (MDA), disponíveis em: <http://www.mda.gov.br>. Acesso em: 2 jul. 2014.

${ }^{420}$ POPHAM, Peter. The price of food is at the heart of this wave of revolutions. The Independent, Londres, 27 fev. 2011. Disponível em: <http://www.independent.co.uk/news/word/afri$\mathrm{ca} /$ the-price-of-food-is-at-the-heart-of-this-wave-of-revolutions-2226896.html>. Acesso em: 23 jun. 2014.

421 JĖZE, Gaston. Principios generales del derecho administrativo, p. 54.

${ }^{422}$ ECHEVARRÍA, Santiago García. Política de subvenciones: (la inspección financiera en el sector mixto de la economía). Paper n. 15. Universidad de Alcal/Instituto de Direción y Organización de Empresas (IDOE), 1983. p. 10. Disponível em: <http://dspace.uah.es/dspace/ handle/10017/3074>. Acesso em: 5 jun. 2014.

423 OLIVEIRA, Regis Fernandes de. Curso de direito financeiro, p. 452. 


\section{•• O orçamento como instrumento de intervenção no domínio econômico}

específicos, bem se sabe que estes, na maioria das vezes, deixam de atendê-las ou realizá-las, até mesmo por falta de específica previsão legal.

Santiago García Echevarría ${ }^{424}$ sustenta que seria necessário delimitar as subvenções e sua realização ao longo do tempo, suprimindo-as gradativamente de maneira que os riscos envolvidos em todo o processo voltem a ser assumidos totalmente por seus beneficiários e que, por consequência, devolva-se ao orçamento do Estado a flexibilidade necessária para poder, do ponto de vista político, social e econômico, atender a novas necessidades, até mesmo imprevisíveis. $\mathrm{O}$ autor ${ }^{425}$ pondera:

Una política de subvenciones no puede acumular las nuevas subvenciones junto con las viejas y que, por lo tanto vaya deteriorando la eficacia de las transferencias públicas, de manera que el Estado no logre los grados necesarios de eficacia para poder realizar las tareas que le imponen.

Além da delimitação proposta pelo autor, seria necessário empreender maior fiscalização acerca do cumprimento das contrapartidas impostas em lei, bem como melhor planejar a implementação das políticas de subvenção econômica e, assim, inserir seu destino na peça orçamentária e no ato de liberação, e não mais em medidas provisórias ou mediante criação de despesas extraordinárias.

Afinal, como a história mostra, embora ninguém esteja isento de prestar contas do que recebeu do Poder Público, os diversos episódios de corrupção impõem, além das medidas sugeridas, que se retome a consciência ética neste País com relação ao dinheiro público e ao orçamento ${ }^{426}$.

${ }^{424}$ ECHEVARRÍA, Santiago García. Política de subvenciones: (la inspección financiera en el sector mixto de la economía). Paper n. 15. Universidad de Alcal/Instituto de Direción y Organización de Empresas (IDOE), 1983. p. 11. Disponível em: <http://dspace.uah.es/dspace/ handle/10017/3074>. Acesso em: 5 jun. 2014.

${ }^{425}$ ECHEVARRÍA, Santiago García. Política de subvenciones: (la inspección financiera en el sector mixto de la economía). Paper n. 15. Universidad de Alcal/Instituto de Direción y Organización de Empresas (IDOE), 1983. p. 11. Disponível em: <http://dspace.uah.es/dspace/ handle/10017/3074>. Acesso em: 5 jun. 2014.

426 TORRES, Ricardo Lobo. Tratado de direito constitucional, financeiro e tributário: o orçamento na Constituição, p. 58. 